\title{
Investigation on culture and health status of Mrigal Cirrhinus cirrhosus from the farming system of Mymensingh region
}

\author{
G. U. Ahmed*, K. Konica, M. F. Ali ${ }^{1}$ and T. Khatun \\ Department of Aquaculture, Bangladesh Agricultural University, Mymensingh-2202, Bangladesh and ${ }^{1}$ Department of \\ Aquaculture, Skeikh Fajilatunnesa Mujib Fisheries College, Melandah, Jamalpur, *E-mail: giasa50@gmail.com
}

\begin{abstract}
Indian major carp, Cirrhinus cirrhosus was considered to monitor culture and health status in farm condition from Bhaluka and Muktagacha of Mymensingh region of Bangladesh for a period of seven months starting from September, 2010 to March, 2011. Monthly sampling was carried out for growth and health condition. Samples of skin and muscle, gill, liver and kidney were observed by clinical and histological techniques. Water temperature was at unfavorable levels but, dissolved oxygen, $\mathrm{pH}$, alkalinity, ammonia and nitrite of water were within the favorable range for fish culture during the months of December and January. Clinically weak body, rough skin, scale loss, thick gill filaments, ulcer and gray brownish color were observed. Among the affected fish organs like skin, muscle and gill were found to be more affected than those of the internal organs, liver and kidney. Major pathologies in the skin and muscle were loss of epidermis and dermis, presence of fungal granuloma, fungal hyphae, necrosis, hemorrhages, vacuums and melanocytes. Protozoan cysts, clubbing, hemorrhages, necrosis and hypertrophy were found in the gill. Necrosis, hemorrhage, pyknosis and vacuums were observed in liver. Common pathological signs like necrosis, hemorrhage, pyknosis, vacuums and degenerated kidney tubules were noticed in kidney. Overall, in the clinical and histopathological studies fishes were found to be more affected during the colder months i.e., December and January. Whereas, in the month of February the pathological condition of fish gradually started to heal up. In histopathological observation, fishes of Bhaluka farms were more affected than that of Muktagacha fish farms. Epizootic ulcerative syndrome (EUS) and protozoan diseases were noticed in Bhaluka fish farms.
\end{abstract}

Keywords: Cirrhinus cirrhosus, Clinical and Pathological condition

\section{Introduction}

The mrigal (Cirrhinus cirrhosus) is the most widely farmed species among the Indian major carps of the Indo-Gangetic floodplains of Bangladesh, India and Pakistan. It belongs to the family Cyprinidae of order Cypriniformes. It has advantages for possessing some special characteristics like higher disease resistance capacity, can tolerate wide range of environmental conditions and fast growing fish among the Indian major carps. It is also considered as an excellent food item, especially when the fishes are of moderate size. The mrigal fish culture enables to improve the socio-economic condition of the people of Bangladesh and can keeps contribution to national economy.

For an increased production farmers of Mymensingh region are interested in semi-intensive fish culture. As the culture of Indian major carps has intensified there has also been an increased in the incidence of disease outbreak if due attention are not given. In Bangladesh fishes are suffered from various diseases such as epizootic ulcerative syndrome (EUS), fungal, parasitic and bacterial infections (Chowdhury et al., 1999). In most cases hemorrhages, septicemia, lesions, gill damage are common symptoms of the diseased fish (Chowdhury, 1993 and 1998). Subasinghe (1995) suspected that water quality parameters such as total hardness, total alkalinity, dissolved oxygen, $\mathrm{pH}$, fluctuation of temperature, ammonia, presence of fertilizers and pesticides could be associated with outbreak of diseases. Thus, maintenance of good water quality, nutrition, brood stock, species composition, stocking density etc. can control or at least reduce the outbreak of diseases in fishes. Indian major carps are highly susceptible to diseases in comparison to Chinese and European carps (Lilley et al., 1992). Generally the epidemic occurs in the winter season (November to February) when temperature declines.

Clinical and histological procedures are important tools used to diagnose disease in fish. Ahmed and Haque (1999) found that clinical symptoms like grey white necrotic areas increase in December, January and February in various carp species of Bangladesh. Histology has been successfully used throughout the world. In Bangladesh, however, histological technique has limited application for disease diagnosis (Moniruzzaman, 2000). Ahmed et al. (1998) observed gill pathology having monogenetic trematode in juvenile of Indian major carps. Considering the above, the present study was undertaken to observe production and health status of mrigal from the farms of Mymensingh regions. 


\section{Materials and Methods}

The experiment was carried out for a period of seven months from September, 2010 to March, 2011. Four farms were selected for the present study. Two ponds (Pond 1 and Pond 2) of two fish farms were located in Bohuli village of Bhaluka upazilla, Mymensingh district. It was about $40 \mathrm{~km}$ away from Mymensingh sadar. On the other hand, the rest of two ponds (Pond 3 and Pond 4) of two fish farms were located in Digholgoan village of Muktagacha Upazilla of Mymensingh district which was $16 \mathrm{~km}$ west from Mymensingh sadar. The area of pond $1\left(P_{1}\right)$, pond $2\left(P_{2}\right)$, pond $3\left(P_{3}\right)$ and pond $4\left(P_{4}\right)$ were 5.0, 2.5, 0.45 and 0.40 acres having water depth of 61.0 to $91.0 \mathrm{~cm}, 91.0$ to $137.0 \mathrm{~cm}, 91.0$ and $76.0 \mathrm{~cm}$, respectively. The ponds were prepared by application of rotenone at a dose of $1 \mathrm{ppm}$ for killing undesirable organisms and lime was applied at a dose $1 \mathrm{~kg} / \mathrm{dec}$. Both the inorganic (Urea and TSP) and organic fertilizers (cow dung) were used. Doses were maintained as urea $100 \mathrm{~g}$, TSP $90 \mathrm{~g}$ and cow dung $4 \mathrm{~kg}$ per dec. Chicken manures were soaked with sac in $\mathrm{P}_{1}$. Ponds were stocked with 10 to $15 \mathrm{~cm}$ mrigal fry. Stocking density of $P_{1}, P_{2}, P_{3}$ and $P_{4}$ were 240, 220, 220 and 225 fry per dec, respectively. CP, Mega and ACl feed were applied in the ponds. Feed was given twice a day at the rate of $5 \%$ of the fish body weight in each pond. In $\mathrm{P}_{3}$ water exchange facilities was available.

Water quality parameters like temperature, $\mathrm{pH}$, dissolved oxygen, alkalinity, ammonia and nitrite were determined by using water quality parameter kits. Initial and final weight $(\mathrm{g})$ of the fishes was measured at the beginning and at the end of the experiment. Clinical symptoms were observed immediately to record any injury, infection and abnormalities. Samples from various organs such as skin, muscle, gill, liver and kidney were collected and fixed in fixatives for histological analysis. The samples were then arranged in steel rack and dehydrated, cleared and infiltrated in an automatic tissue processor (SHANDON, Citadel 1000). The samples were then embedded with molten wax, steel mold and perforated plastic holder. Trimming was done from side and surface of the blocks with the help of scalpel and a microtome, respectively. The blocks were then sectioned at 5-7 micrometers by the microtome machine (Leica JUNG RM 2035). The sections were then stained with haematoxylin and eosin stains. After staining the sections were mounted with Canada balsam and covered by cover slips. Photomicrographs of the stained sections were done by using photomicroscope.

\section{Results and Discussion}

Water quality parameters are important considerations of production and health issues in fishes. It was observed that the highest water temperature $\left(29.0^{\circ} \mathrm{C}\right)$ was recorded during March. Ahmed et al. (2009) observed that the value of temperature was $26.0^{\circ} \mathrm{C}$ during March in freshwater bodies of Mymensingh. In contrast the lowest temperature $\left(18.0^{\circ} \mathrm{C}\right)$ was recorded in January. Ahmed et al. (2007) measured water temperature ranged from 19.5 to $29.5^{\circ} \mathrm{C}$, while in December and January it was $19.5^{\circ} \mathrm{C}$ from two different farms of Mymensingh district. The dissolved oxygen content was ranged from 7.0 to $10.0 \mathrm{mg} / \mathrm{l}$ in four ponds. Ahmed et al. (2009) recorded dissolved oxygen ranged from 3.0 to 5.5 in four beels of Mymensingh. The dissolved oxygen content of water was fair in respect of fish culture. The $\mathrm{pH}$ values were ranged from 7.1 to 7.7 in four ponds. Ahmed et al. (2007) recorded that $\mathrm{pH}$ values ranged from 7.0 to 7.5 in different farms of Mymensingh district. So, from the above findings it can be mentioned that $\mathrm{pH}$ values obtained in the present research were within acceptable range for fish culture. Alkalinity of the experimental ponds were varied from 90 to $200 \mathrm{mg} / \mathrm{l}$. Ahmed et al. (2009) found alkalinity varied from 38 to $68 \mathrm{mg} / \mathrm{l}$ in freshwater bodies of Mymensingh region. Reduced level of alkalinity was observed during December and January in the present study which had similarity with the findings of Ahmed and Banu (2001) who observed reduced alkalinity in freshwater bodies of Bangladesh during December and January. Ammonia value was ranged from 0.001 to $0.025 \mathrm{mg} / \mathrm{l}$ in all the ponds. However, it was observed that the values of ammonia were increased in December and January. Akter et al. (2009) observed increased level of ammonia during winter period.

It was seen that the highest growth rate and production were achieved in $P_{2}$ and $P_{3}$ where had lower fish density. This phenomenon indicated that there was a lower community feeding among the fishes which influenced them to take food properly and it might be absent in ponds with higher stocking density. Sardar et al. (1991) observed a decreased growth rate at the higher stocking densities when compared with the lower one and highest percentage of mortality was recorded in Clarias gariepinus fry. 
Clinical observations revealed that fishes from all the ponds were apparently healthy and normal in appearance during the months of September, October and March (Fig. 1). Islam et al. (1999) observed that Indian major carps were found to have less affected during the month of March. However, in the month of November, mild signs like weak body, rough skin and scale loss were observed. According to Roy et al. (2006) rough skin, scale loss was found in November in various small species of open water bodies. It was found that the clinical signs were increased in December and January (Fig. 2). During this period weak body, rough skin, dermal lesions in ventral region, gray brownish color of the body and thick gill filaments were observed. Ahmed and Hoque (1999) monitored that symptoms like gray white necrotic areas increased in December and January in various carp species of Bangladesh. This result was also similar with the finding of Hoque (1998) and Islam et al. (1999) who reported that during the winter month infection was higher in various carp species of Bangladesh. However, Cirrhinus cirrhosus of Bhaluka especially in $\mathrm{P}_{1}$ were clinically more affected compared to the fishes of other ponds and upazillas in the present investigation. Ahmed et al. (2007) found in Anabas testudineus that rough skin, scale loss and mild hemorrhage were observed in December, whereas, hemorrhage with reddish bright spots, fin loss and deep ulcer were evidenced at dorsoventral region of skin during January. According to Akter (2006) $M$. aculeatus and $M$. cuchia of Ailee beel in Bangladesh had rough skin, weak body, red spots and deep ulcer in December to January.

Histopathological examination of the present study showed that skin and muscle were almost normal in months of September, October and March in all the experimental ponds. Ahmed et al. (2007) observed that skin and muscle was normal in September and October in A. testudineus from two different farms of Mymensingh district. Less pathological changes such as loss of epidermis, necrotic muscles and vacuums were observed in November. According to Ahmed et al. (2009) epidermis and dermis were totally lost and some vacuums were seen in dermis and myotomes were arranged in normal fashion in skin and muscle of $M$. cuchia during November. Skin and muscle were severely affected like loss of dermis and epidermis and presence of fungal granuloma, fungal hyphae, necrosis, hemorrhage, vacuums and melanocytes in December and January (Figs. 3 and 4). Parveen et al. (2005) reported that epidermis was totally lost, many fungal granuloma were present in dermis and muscle, myotomes were ruptured and missing in many places during the months of December and January in Gangni Ox-bow Lake. Ahmed et al. (2009) cited that during winter season, increased pathologies were observed like epidermis and part of dermis was lost, highly necrotic and pyknotic muscles contained numerous fungal granulomas, especially towards the months of December and January. Pathological healing was started in February in all the ponds. From the presence of fungal granuloma and fungal hyphae in the muscle of $P_{1}$, it could be mentioned here that the fishes were affected with Epizootic Ulcerative Syndrome (EUS) in January. Hossain et al. (2009) also reported that during winter season, dermis and muscle were severely necrotic having huge vacuums, dermis partly lost, fungal hyphae and fungal granuloma in some small indigenous species.

The gills were found normal in September and October. Akter et al. (2009) observed that structure of gill of $A$. testudineus were almost normal in September and October. Less pathological changes such as hypertrophy, clubbing and few lamellar missing were recorded during November. Increased the pathological changes like presence of protozoan cyst, hypertrophy, lamellar missing, clubbing, hemorrhage, necrosis and primary gill lamellae separation were in the present experiment during December and January (Figs. 5 and 6). Similar findings were also recorded by Hoque (1995) with the gill lamellae of $C$. cirrhosus obtained from a private fish farm of Mymensingh area. Ahmed et al. (1998) found that hypertrophied gill lamellae with loss of secondary gill lamellae were evidence in C. cirrhosus of privately operated ponds. In March, gills were almost healed up to almost normal structure. Numerous protozoan cysts were recorded at the tip of the gill lamellae from $\mathrm{P}_{1}$ and $\mathrm{P}_{2}$ in winter season. From the presence of protozoan cysts in the gill, it was indicated that the fishes of $P_{1}$ and $P_{2}$ were affected with parasitic diseases in December and January. Ahmed et al. (2007) observed that protozoan cysts, marked hypertrophy, hyperplasia and necrosis in A. testudineus from two different farms of Mymensingh district during December and January. 


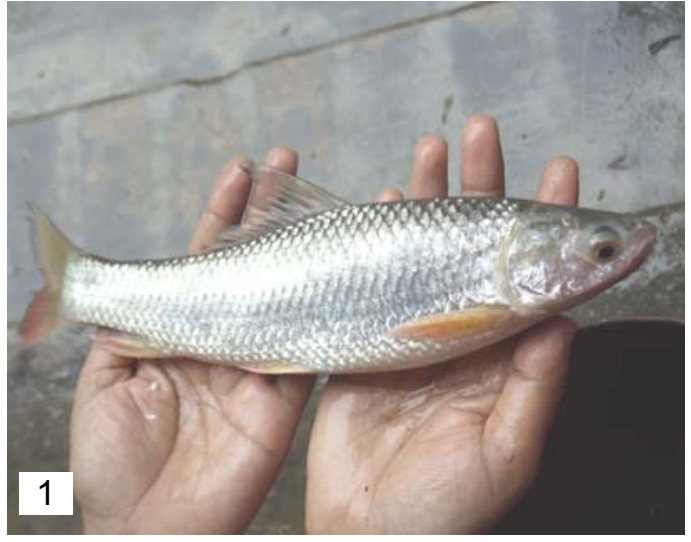

Fig. 1. Healthy appearance of fish in March from $P_{1}$

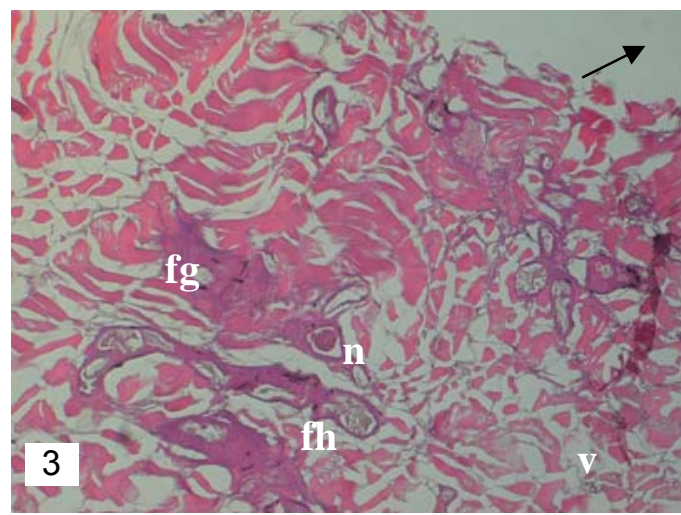

Fig. 3. Section of skin and muscle obtained from $P_{1}$ in January. Epidermis totally lost $(\uparrow)$, necrosis (n), fungal hyphae (fh), fungal granuloma (fg) and vacuums (v) were found in muscle. $\mathrm{H} \& \mathrm{E} \times 235$

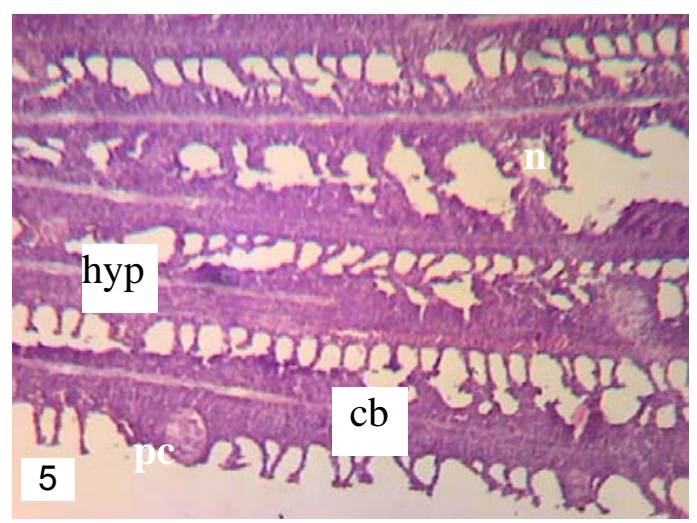

Fig. 5. Section of gill recorded from $P_{1}$ in December. Gill lamellae had numerous protozoan cysts (pc), hypertrophy (hyp), clubbing (cb) and necrosis (n). H \& E $\times 125$

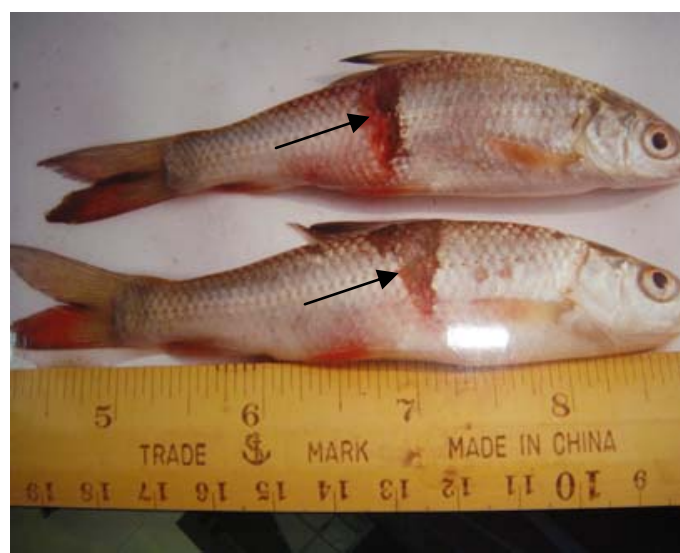

Fig. 2. Ulcer and gray brownish color $(\uparrow)$ of fish in January from $\mathrm{P}_{1}$

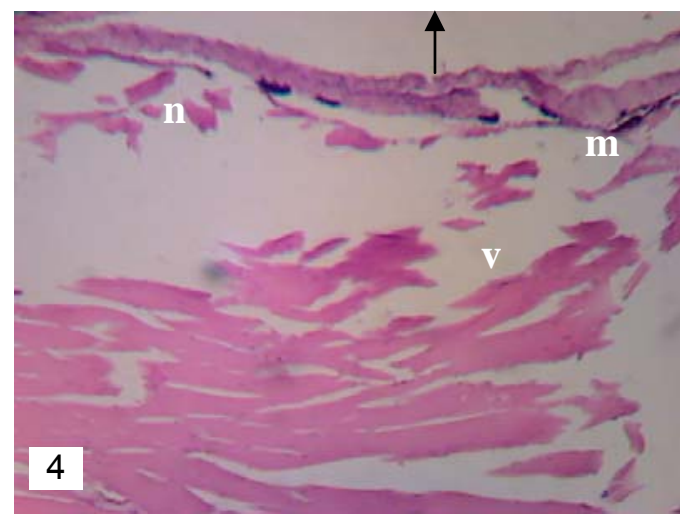

Fig. 4. Section of skin and muscle obtained from $\mathrm{P}_{4}$ in December. Epidermis totally lost, dermis partly lost $(\uparrow)$, sloughed off from muscle and muscle had wide vacuums (v), necrosis ( $n$ ) and melanocytes (m). H \& E × 125

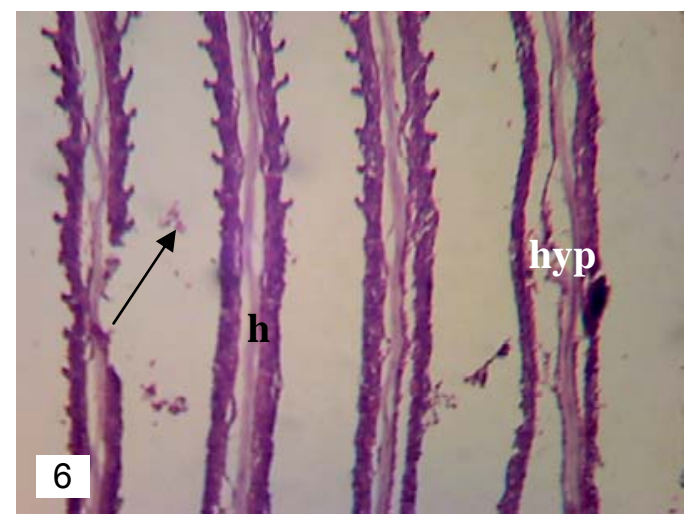

Fig. 6. Section of gill obtained from $P_{3}$ in January. Severely affected gill had lamellar missing ( $\uparrow)$, hypertrophy (hyp) and hemorrhage (h). H \& E × 125 
Liver of fishes had mild necrosis, vacuums and hemorrhage in November. Ahmed et al. (2009) observed that liver had mild necrosis, hemorrhage and vacuums in $M$. cuchia from Ailee beel in November. Severe necrosis, pyknosis, vacuums and hemorrhages were observed during December and January (Figs. 7 and 8). Ahmed et al. (2004) found necrosis, hemorrhage and dense pyknotic cells in $N$. nandus from Kailla beel in the months of December and January. Hossain et al. (2009) recorded severe necrosis of hepatocytes, pyknosis, vacuums, fat droplets and hemorrhages during December and January. However, pathological healing was started in February in fishes of all the ponds and in March liver pathology was also recovered to give normal structure.

In case of kidney almost normal kidney structure were found in September, October and March. But in November, pathologies in kidney were found to be started with mild necrosis and empty spaces. Kidney was severely affected in December and January, with pathological signs such as degenerated kidney tubules, hemorrhage, necrosis, vacuums and pyknosis in many places (Figs. 9 and 10). Similar pathological symptoms of kidney of Indian major carps were observed by Hoque (1998) and Islam (1999). Ahmed et al. (2004) mentioned that the kidney had marked necrosis with wide vacuums and pyknotic cells in N. nandus and C. punctatus from Kailla beel in December and January. Pathologies were started to recover in fishes of all the ponds in February. Liver and kidney were less affected than external organs like skin and gill in this present study.

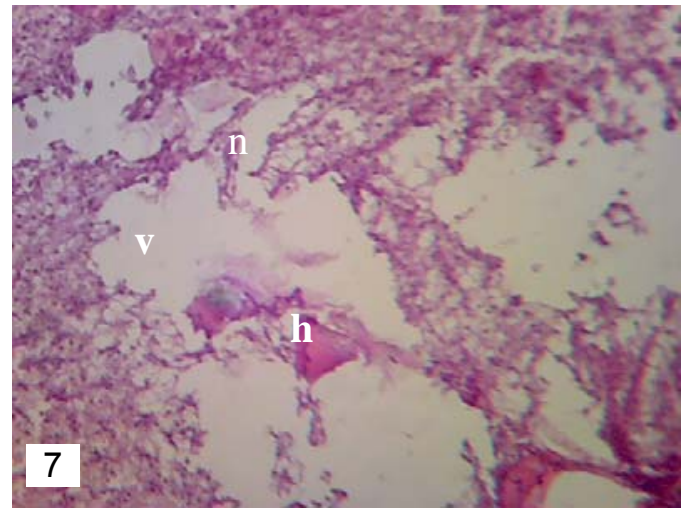

Fig. 7. Section of liver obtained from $P_{2}$ in January Severe necrotic $(n)$ hepatocytes, hemorrhage $(h)$ and vacuums $(v)$ were observed. $H \& E \times 235$

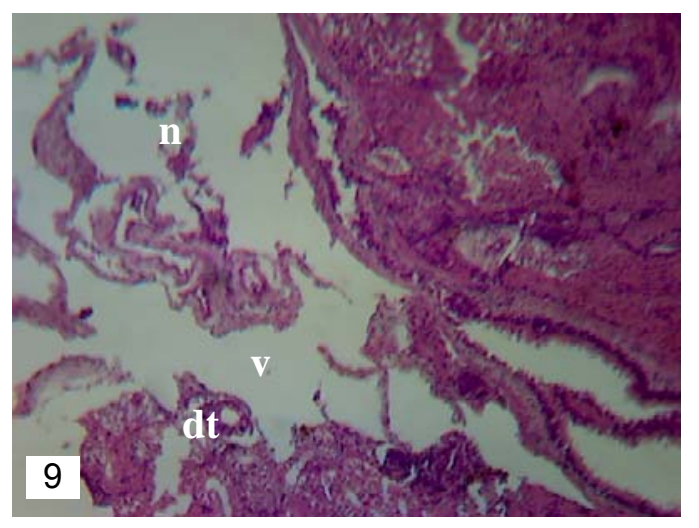

Fig. 9. Photomicrograph of kidney obtained from $P_{1}$ in January. Kidney tubules were degenerated (dt) and resulted in wide vacuums (v) and marked necrosis ( $n$ ). $H \& E \times 125$

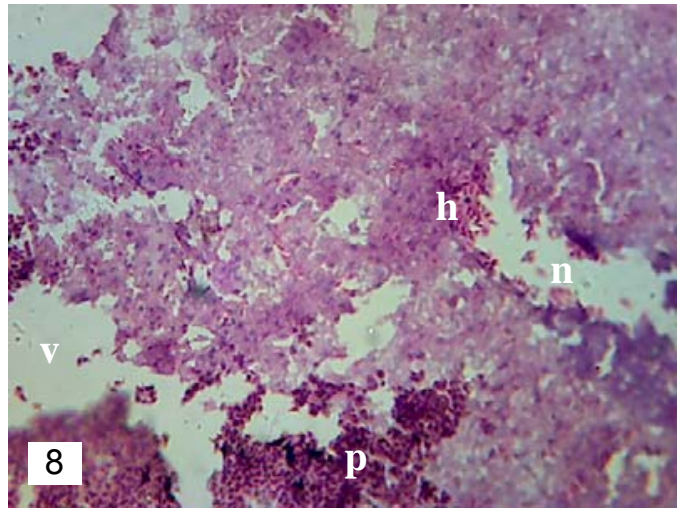

Fig. 8. Photomicrograph of liver obtained from $P_{3}$ in January. Marked necrosis ( $n)$, hemorrhage (h), pyknosis $(p)$ and vacuums $(v)$ were observed. $H \& E \times$ 235

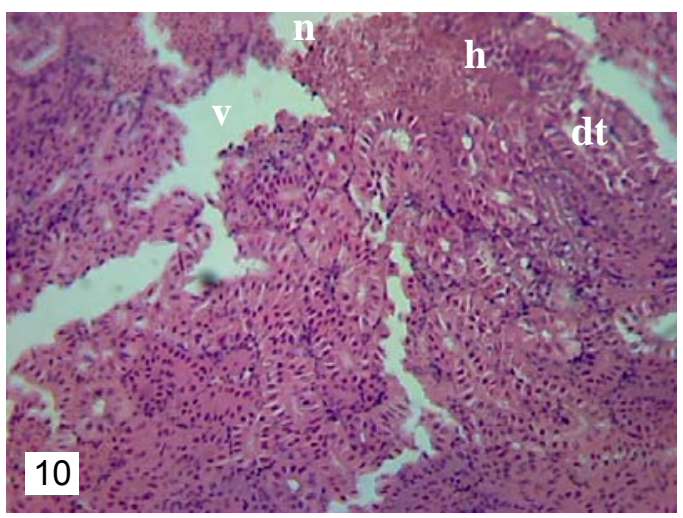

Fig. 10. Section of kidney obtained from $P_{3}$ in January. Degenerated kidney tubules (dt), necrosis (n), hemorrhage $(h)$ and vacuums $(v)$ were observed. $H$ \& E $\times 125$ 
Clinically and histopathologically, it was observed that, sampled fishes were found normal during the months of September and October. Conversely, in November mild pathological changes in organs were observed. However, fishes were more affected when temperature was reduced in winter season. Ahmed et al. (2009) found that fishes of all the Ox-bow lakes were affected in the colder months of the year i.e. in December and January when water temperature drops to minimum levels $\left(16^{\circ} \mathrm{C}\right)$. Ahmed and Hoque (1999) mentioned that in freshwater fish, EUS outbreak was severe during cooler months of the year when temperature and alkalinity were reduced at their minimum levels. So, it could be assumed that low temperature, along with alkalinity might have played an important role in outbreak of diseases like EUS and protozoan disease. On the other hand, reduced pathological changes were recorded in February and March. Organ wise, gill had an increased pathology in all the ponds and months when compared to other organs.

\section{Conclusion}

In the present investigation most of the examined fishes of four ponds were more or less normal and healthy from external observations. But histopathologically, a large percentage of the fishes were affected by numerous protozoan cysts and fungal granuloma during the cold period in $\mathrm{P}_{1}$ of Bhaluka. This might be due to application of raw chicken manure to the pond and low temperature. Among the farms, clinically and pathologically cultured fishes of farms in Bhaluka were found to be more affected than fishes of the farms of Muktagacha. This is due to poor management practice such as high stocking density, over use of organic fertilizer and lack of regular monitoring. So, steps should be taken to overcome the problems. Attention should be given towards cooler months of the year when fishes suffered from various diseases. Stocking density should be reduced by regular harvesting during the period, liming and salting prior to winter season, balance diets, water quality should be in controlled condition which will ultimately reduce stress, infection and diseases in fishes.

\section{References}

Ahmed, G.U., Hossain, M.M. and Hossain, M.S. 2009. Histopathology of diseases of an air breathing teleost Anabas testudineus (Bloch) from freshwater fisheries of Bangladesh. Int. J. Sustain. Agril. Tech., 5(4): 75-81.

Ahmed, G.U. and Hoque, M.A. 1999. Mycotic involvement in the epizootic ulcerative syndrome of freshwater fishes of Bangladesh: A histopathological study. Asian Fish. Sci., Philippines, 12: 381-390.

Ahmed, G.U., Dhar, M., Khan, M.N.A. and Choi, J.S. 2007. Investigation of diseases of Thai koi, Anabas testudineus (Bloch) from farming conditions in winter. J. of Life Sci., 17 (10): 1309-1314.

Ahmed, G.U., Hossain, M.M. and Hassan, M.M. 2009. Seasonal variation of disease and pathology of a perch, Nandus nandus (Hamilton) from Oxbow-lake fisheries of Bangladesh. Eco-friendly Agril. J., 2(8): 761-767.

Ahmed, G.U. and Banu, A.N.H. 2001. Investigation on diseases of some small indigenous freshwater fishes of Bangladesh. A final report submitted to Bangladesh Agricultural Research Council. Farm gate, Dhaka. 67 pp.

Ahmed, G.U., Akter, M.N., Nipa, S.A. and Hossain, M.M. 2009. Investigation on health condition of a freshwater eel, Monopterus cuchia from Ailee beel, Mymensingh, Bangladesh. J. Bangladesh Agril. Univ., 7(2): 419-424.

Ahmed, G.U., Ferdous, M.J. and Hossain, M.S. 2009. Diseases occurrence and histopathology of catfish and snakehead in Ox-bow lake fisheries of Bangladesh. J. Subtrop. Agric. Res. Dev., 7(3): 638-644.

Ahmed, G.U., Haque, M.M. and Hoque, M.J. 1998. Gill pathology of juvenile carps in nursery ponds. Bangladesh J. Fish. Res., 2(1): 63-67.

Ahmed, G.U., Parveen, R. and Sultana, S. 2004. Disease investigation of small indigenous fishes from Kailla beel in Mymensingh area. J. Bangladesh Agril. Univ., 2(2): 305-311.

Akter, M.N., Ahmed, G.U. and Hossain, M.S. 2009. Seasonal variation of gill pathology of a climbing perch in lake fisheries of Bangladesh. Int. J. Anim. Fish. Sci., 2(3): 208-213.

Akter, S., Ahmed, G.U., Roy, M.K. and Akter, N. 2006. Investigation of the diseases of some small indigenous fish species from Ailee beel, Mymensingh. Progress. Agric., 17 (1): 219-225.

Chowdhury, M.B.R. 1993. Research priorities for microbial fish disease and it's control in Bangladesh. In: Proceeding of the Workshop on Research Priorities of Bangladesh for fish health, disease prevention and pathology (ed. A. Tollervey), 8-11 $\mathrm{pp}$. 
Chowdhury, M.B.R. 1998. Involvement of aeromonad and pseudomonads in diseases of farmed fish in Bangladesh. Fish Pathol., 33: $247-254$.

Chowdhury, M.B.R., Islam, M.A., Hossain, M.I., Sarker, M.A. and Mojumder, B. 1999. Involvement of aeromonads in ulcer disease in farmed fishes. BAU Res. Prog., 10: 140-146.

Haque, M.A. 1998. Histopathological study of epizootic ulcerative syndrome (EUS) in Indian major carps from Mymensingh area of Bangladesh. M.S. Thesis, Department of Aquaculture, Bangladesh Agricultural University, Mymensingh. 56 pp.

Haque, M.J. 1995. Gill pathology of juvenile carps of nursery ponds. M.S. Thesis. Department of Aquaculture, Bangladesh Agricultural University, Mymensingh.

Hossain, M.M., Ahmed, G.U., Tazri, Z. and Haque, M.A. 2009. Clinical and pathological investigation of diseases in some small indigenous species (SIS) from fish markets of Mymensingh. Intl. Biores., 7(3): 1-6.

Islam, M.J. 1999. Investigation into carp diseases through histopathological observations. M.S. Thesis. Department of Aquaculture, Bangladesh Agricultural University, Mymensingh. 79 pp.

Islam, M.J., Ahmed, G.U., Islam, T., Haque, M.A. and Sarkar, M.G.A. 1999. Gill pathology of carp's disease from farming systems of Bangladesh. Bangladesh J. Fish., 22(2): 113-118.

Islam, M.S., Ahmed, G.U. and Mazid, M.A. 1999. Observation on the production of Indian major carps through management on farmer ponds in a polyculture system. Bangladesh J. Fish., 22(2): 53-57.

Lilley, J.H., Philips, M.J. and Tonguthai, K. 1992. A review of epizootic ulcerative syndrome in Asia, Publ. Aquatic Animal Health Research. Institute and Network of Aquaculture Centres in Asia Pacific. Bangkok, Thailand. 73 pp.

Moniruzzaman, M. 2000. Investigation on disease of some small indigenous freshwater fishes of Bangladesh. M.S. Thesis, Department of Aquaculture, Bangladesh Agricultural University, Mymensingh. 64 pp.

Parveen, R., Ahmed, G.U. and Lokman Ali, M. 2005. Seasonal variation of diseases of some small indigenous fishes from Ox-bow lake fisheries of Bangladesh. Pakistan J. Zool., 37(1): 53-59.

Roy, M.K., Ahmed, G.U., Akter, S. and Akter, N. 2006. Study of health condition of small indigenous freshwater fishes of Ailee beel Mymensingh. Progress. Agric., 17 (1): 201-209.

Sarder, M.R.I., Ahmed, G.U., Mollah, M.F.A. and Haq, M.S. 1991. Effect of stocking density on the growth of African catfish, Clarias gariepinus fry. Bangladesh J. Fish., 14(1-2): 37-40.

Subasinghe, R.P. 1995. Note on Fish Disease Diagnosis and Health Management Training Workshop held from $22^{\text {nd }}$ to $25^{\text {th }}$ February, FRI, Mymensingh, 3-21 pp. 